\title{
PERBEDAAN MODEL PEMBELAJARAN PROBLEM POSING DAN PROBLEM BASED LEARNING TERHADAP KEMAMPUAN BERPIKIR KREATIF MATEMATIS SISWA
}

\author{
${ }^{1}$ Siti Yuliyanti, ${ }^{2}$ Yayah Huliatunisa, ${ }^{3}$ Suparta Rasyid, ${ }^{4}$ Yohamintin, ${ }^{5}$ Irawati Sabban \\ ${ }^{1}$ Universitas Muhammadiyah Tangerang-Jalan Perintis Kemerdekaan I/33 Tangerang \\ ${ }^{2}$ Universitas Pendidikan Indonesia-Jalan Dr. Setiabudi No. 229-Bandung \\ ${ }^{3}$ Universitas Syiah Kuala-Jalan Teuku Nyak Arief No. 441, Darussalam-Banda Aceh \\ ${ }^{4}$ Universitas Bhayangkara Jakarta Raya-Jalan Rm Dalam No. 46-Jakarta Selatan \\ ${ }^{5}$ Universitas Pasifik Morotai-Morotai Selatan-Maluku Utara \\ Email:sitiyuliyanti3@gmail.com-yhuliatunisa13@gmail.com
}

\begin{abstract}
Abstrak
Berdasarkan data sebanyak 53,84\% siswa kelas IV di SDN Cikuya III Kabupaten Tangerang mendapat nilai matematika dibawah KKM (70), kesulitan ketika diberikan soal hitungan matematika terutama bangun datar, belum terbiasa berpikir kreatif matematis, kesulitan dalam pemahaman konsep, serta guru menggunakan model pembelajaran ceramah menjadi latar belakang penelitian ini. Dampaknya siswa malas, sangat pasif, tidak tertarik sampai malas mengulang kembali pelajaran dirumah. Tujuan penelitian ini untuk mengetahui perbedaan tingkat berpikir kreatif matematis siswa setelah mendapat perlakuan antara model pembelajaran Problem Posing dan Problem Based Learning pada pemelajaran matematika materi bangun datar. Penelitian kuantitatif ini menggunakan metode eksperimen jenis true experimental design. Jumlah populasi dan sampel menggunakan total sampling yakni 52 siswa kelas IV A (29) sebagai kelas eksperimen 1 menggunakan Problem Posing, dan B (23) sebagai kelas eksperimen 2 menggunakan Problem Based Learning. Teknik pengumpulan data melalui observasi, wawancara, dokumentasi dan tes, serta statistic deskriptif dan statistic inferensial sebagai teknik analisis data. Kesimpulan diperoleh, Problem Posing yang diterapkan di kelas IV A memiliki nilai lebih tinggi dari nilai sebelum diberikan Problem Posing. Problem Based Learning yang diterapkan pada kelas IV Bmemiliki nilai lebih tinggi dari nilai sebelum diberikan Problem Based Learning dengan nilai postest. Sehingga model pembelajaran Problem Based Learning dianggap layak meningkatkan kemampuan berpikir kreatif matematis siswa pada mata pelajaran matematika materi bangun datar.
\end{abstract}

Kata Kunci: Model Pembelajaran, Problem Posing, Problem Based Learning, Berpikir Kreatif Matematis

\begin{abstract}
Based on data as many as $53.84 \%$ of fourth grade students at SDN Cikuya III Tangerang Regency got math scores below the KKM (70), difficulties when given math problems, especially flat shapes, not used to mathematical creative thinking, difficulties in understanding concepts, and teachers using models Lecture learning is the background of this research. The impact is that students are lazy, very passive, not interested until they are lazy to repeat lessons at home. The purpose of this study was to determine the difference in the level of students' mathematical creative thinking after receiving treatment between the Problem Posing and Problem Based Learning learning models in learning mathematics with flat shapes. This quantitative research uses an experimental method of true experimental design. The number of population and samples used total sampling, namely 52 students of class IV A (29) as experimental class 1 using Problem Posing, and B (23) as experimental class 2 using Problem Based Learning. Data collection techniques through observation, interviews, documentation and tests, as well as descriptive statistics and inferential statistics as data analysis techniques. The conclusion is obtained, Problem Posing applied in class IV A has a higher value than the value before being given Problem Posing. Problem Based Learning applied to class IV B has a higher value than the value before being given Problem Based Learning with a posttest score. So that the Problem Based Learning learning model is considered feasible to improve students' mathematical creative thinking skills in mathematics subjects with flat shapes.
\end{abstract}

Keywords: Learning Model, Problem Posing, Problem Based Learning, Mathematical Creative Thinking 


\section{PENDAHULUAN}

Menciptakan proses pembelajaran menyenangkan serta inovatif dengan tidak menghilangkan tujuan pembelajaran itu sendiri merupakan tuntutan guru sebagai upaya meningkatkan minat belajar siswa. Tujuan pembelajaran dapat tercapai jika dapat menciptakan proses belajar mengajar bermakna, yang dapat diwujudkan melalui keterlibatan siswa secara langsung. Upaya mewujudkan proses pembelajaran bermakna tersebut membutuhkan model pembelajaran bervariatif dan inovatif.

Salah satu pembelajaran yang mampu mengembangkan kemampuan berpikir kreatif siswa dalam menyelesaikan suatu masalah adalah mata pelajaran matematika. Kemampuan berpikir kreatif sangat penting dalam pembelajaran matematika, karena dengan berpikir kreatif, siswa dapat menemukan jawaban dari soal-soal matematika dengan cara mereka sendiri secara tepat. Untuk memenuhi keberhasilan tersebut, guru sangat berperan tinggi dalam prosesnya. Guru dituntut mampu menggunakan dan mengembangkan berbagai model pembelajaran tepat yang berfungsi sebagai pedoman dalam merencanakan dan melaksanakan aktivitas belajar mengajar untuk membantu siswa mencapai tujuan belajarnya.

Penelitian ini bertujuan mengetahui perbedaan penerapan model pembelajaran Problem Posing dan Problem Based Learning terhadap kemampuan berpikir kreatif matematis siswa sekolah dasar. Siswa kelas IV SDN Cikuya III Kabupaten Tangerang berjumlah 52 (kelas A: 29 dan kelas B: 23) kesulitan memecahkan masalah matematika secara kreatif. Hal ini didasarkan pada hasil observasi awal bahwa nilai UTS dari total keseluruhan siswa kelas IV, terdapat 28 siswa $(53,84 \%)$ mendapat nilai matematika di bawah KKM (70), serta hasil wawancara dengan guru, siswa selalu merasa kesulitan ketika diberikan soal hitungan matematika terutama bangun datar, siswa belum terbiasa berpikir kreatif matematis, banyak kesulitan dalam pemahaman konsep, serta guru masih menggunakan model pembelajaran ceramah. Hal ini berdampak siswa merasa malas, sangat pasif, tidak tertarik sampai malas mengulang kembali pelajaran di rumah.

Berdasarkan hal tersebut, penerapan suatu model pembelajaran menyenangkan dan mendorong siswa mampu memecahkan masalah pembelajaran dengan mandiri serta tepat, agar dapat meningkatkan kemampuan berpikir kreatifnya dalam menyusun dan 
menyelesaikan soal-soal matematika sangat dibutuhkan, seperti model pembelajaran Problem Posing dan Problem Based Learning.

Tujuan kurikulum 2013 mengarah kepada standar kompetensi lulusan 3 dimensi, yaitu afektif, kognitif dan psikomotor. Standar kompetensi tersebut salah satunya dapat ditempuh melalui materi ajar atau pembelajaran terprogram dan tersusun dalam sebuah teks yang kemudian digunakan dalam kegiatan pembelajaran (Rozak 2014). Hal lain yang dapat mengarah pada pencapaiannya adalah bagaimana mengemas pembelajaran secara tepat bersifat tematik integrative.

Pembelajaran tematik pada dasarnya merupakan praktik pengajaran yang dilandasi oleh salah satu model pembelajaran terpadu (integrated instruction). Pembelajaran tematik ini dapat pula dimaknai sebagai suatu praktik pengajaran yang mendorong peserta didik baik individu maupun kelompok untuk aktif mengeksplor, menganalisis, menemukan prinsip ilmu pengetahuan secara menyeluruh, bermakna, dan dapat dipercaya (Majid 2014). Memiliki kelebihan dibandingkan pembelajaran konvensional yakni: menyenangkan, memberikan pengalaman, hasil belajar yang (bertahan lama, berkesan, dan bermakna), mengembangkan keterampilan berpikir anak, menumbuhkan keterampilan sosial, menumbuhkan sikap (toleransi, komunikasi, dan tanggap), serta menyajikan kegiatan bersifat nyata (Ahmadi and Amri 2014).

Model pembelajaran adalah kerangka konseptual yang melukiskan prosedur sistematik dan mengorganisasikan pengalaman belajar untuk mencapai tujuan belajar tertentu serta berfungsi sebagai pedoman para perancang pembelajaran dan para pengajar dalam merencanakan dan melakukan aktivitas pembelajaran (Ibrahim (2000) dalam (Septian and Rizkiandi 2017).

Model pembelajaran inovatif telah banyak ditawarkan oleh para ahli, yang dapat memfasilitasi siswa dapat terlibat langsung dalam proses pembelajaran, seperti model pembelajaran Problem Posing dan Problem Based Learning. Penggunaan pendekatan Problem Posing dalam proses pembelajaran disarankan oleh para ahli karena memiliki keunggulan. Kegiatan membuat soal dalam Problem Posing dapat mengembangkan kemampuan berpikir kreatif siswa dan meningkatkan kemampuan siswa dalam menyelesaikan masalah (Silver 1994); (English 1995); dan (Lavy and Shriki 2007). Problem Posing juga membantu siswa mengembangkan kemampuan berpikirnya dengan cara yang 
fleksibel (Kilic 2013). Berkembangnya kemampuan siswa dalam menyelesaikan masalah diharapkan dapat meningkatkan prestasi belajarnya. Freire (1970) dalam (Miftahul 2013) 'Problem Posing Learning merujuk pada strategi pembelajaran yang menekankan pemikiran kritis demi tujuan pembebasan'.

Selain pendekatan Problem Posing, pendekatan Problem Based Learning juga dianggap mampu mengatasi masalah yang berkaitan dengan prestasi, dan kemampuan berpikir kreatif. Pendekatan Problem Based Learning menghadapkan siswa pada masalah yang autentik dan kompleks (Duch, Groh, and Allen 2001); (Arends. R. I 2012). Keterlibatan siswa dengan masalah dan proses penyelidikan masalah akan menstimulus siswa untuk mengembangkan kemampuan kognitifnya. Kriteria masalah yang digunakan dalam Problem Based Learning haruslah berkaitan dengan dunia nyata dan ill-structured (Tan and Simpson 2008); (Arends. R. I 2012). Selain itu tahap penyelidikan pada Problem Based Learning membutuhkan kemampuan berpikir kritis dan situasi open ended yang nantinya dapat memunculkan kemampuan berpikir kreatif (Arends. R. I 2012). Barrow (1980) dalam (Miftahul 2013) mendefinisikan Pembelajaran Berbasis Masalah (Problem Based Learning) sebagai 'Pembelajaran yang diperoleh melalui proses menuju pemahaman akan resolusi suatu masalah. Masalah tersebut dipertemukan pertama-tama dalam proses pembelajaran'. Model pembelajaran yang melatih dan mengembangkan kemampuan untuk menyelesaikan masalah berorientasi pada masalah otentik dari kehidupan aktual siswa, untuk menstimulus kemampuan tingkat tinggi (Slameto 2010). (Ngalimun 2013) Model Problem Based Learning ialah model yang melibatkan siswa dalam memecahkan masalah, dengan awal pembelajaran menyajikan masalah nyata bagi siswa kemudian diselesaikan melalui penyelidikan dan diterapkan dengan menggunakan pendekatan pemecahan masalah. (Mairing 2018) mengatakan bahwa pemecahan masalah adalah sebagai proses berpikir yang diarahkan untuk memperoleh jawaban dari masalah. Berpikir adalah suatu proses sehingga pemecahan masalah dapat dipandang sebagai suatu proses. Dengan demikian, proses siswa dalam memperoleh jawaban dalam pemecahan masalah lebih diperhatikan dibandingkan dengan jawabannya.

Pembelajaran matematika bertujuan supaya siswa memiliki kemampuan penalaran tinggi melalui latihan memecahkan masalah, membuat keputusan dan kesimpulan. Dengan harapan pembelajaran seperti ini dapat membuat siswa terlatih berpikir kritis dalam 
menyelesaikan persoalan-persoalan. Pembelajaran matematika yang baik diharapkan siswa dapat memiliki kemampuan berpikir logis, analitis, sistematis, kritis, kreatif dan kemampuan bekerja sama secara efektif sesuai dengan yang tercantum dalam kurikulum 2013 (Nasional 2006).

Menurut (Kreitner and Kinicki 2014) kemampuan (ability) adalah merepresentasikan tanggung jawab karakteristik yang luas dan stabil untuk kinerja maksimal seseorang pada tugas fisik dan mental. Berkaitan dengan hal tersebut, kemampuan mengarah pada sebuah kecakapan menguasai suatu keahlian yang digunakan sedemikian rupa untuk mengerjakan atau menyelesaikan beragam pekerjaan (Huliatunisa 2020). (Sukmadinata 2019) kemampuan (potensi dan nyata) merupakan suatu kecakapan (ability) dalam mengenal, memahami, menganalisis, menilai dan memecahkan masalah-masalah dengan menggunakan (rasio atau pemikiran).

Lampiran I Permendiknas No. 22 Tahun 2006 menyatakan mata pelajaran matematika diberikan kepada semua peserta didik mulai dari sekolah dasar untuk membekali peserta didik dengan kemampuan berpikir logis, analitis, sistematis, kritis, dan kreatif, serta kemampuan bekerja sama. Kompetensi tersebut diperlukan agar peserta didik memiliki kemampuan memperoleh, mengelola, dan memanfaatkan informasi untuk bertahan hidup pada keadaan yang selalu berubah, tidak pasti, dan kompetitif.

Matematika merupakan cabang ilmu universal meliputi ide, gagasan, dan konsep abstrak yang tidak bisa lepas dari kehidupan manusia. Matematika berkembang luas dengan mencakup perkembangan sains dan teknologi (Wulandari 2020). Pembelajaran matematika ditingkat sekolah dasar diharapkan terjadinya penemuan kembali dalam penyelesaian masalah. Penemuan ini maksudnya bagaimana siswa dapat menemukan masalah dalam langkah-langkah signifikan atau sesuai dengan urutan langkah-langkah berpikir secara kritis. Brunner dalam (Heruman 2014) pembelajaran matematika peserta didik di haruskan dapat berpikir secara kritis dalam penyelesaian masalah atau berbagai sumber terkait penemuan dan penyelesaian masalah. Wahyudi dan Kriswand (2013) dalam (Istiqomah and Indarini 2021) konsep matematika yang ditulis secara tersusun dalam bentuk simbol dengan bahasa yang dipilih sangat mudah dipahami dan dicermati. Matematika merupakan sebuah cabang dari pengetahuan eksak dan terorganisasi, ilmu deduktif tentang keluasan atau pengukuran dan letak tentang bilangan-bilangan dan hubungan-hubungan, ide- ide, struktur dan hubungan 
yang diatur menurut urutan logis tentang struktur logika mengenai bentuk yang terorganisasi atas susunan besaran dan konsep mulai dari unsur tidak didefinisikan ke unsur didefinisikan ke aksioma akhirnya teorema dan terbagi ke dalam bidang aljabar, analisis dan geometri (Ali Hamzah 2014). Matematika merupakan ilmu pengetahuan yang berhubungan memelajari tentang simbol-simbol, bilangan-bilangan dan hubungan-hubungan, ide-ide, konsep-konsep, di muat ke dalam bidang aljabar, analisis dan geometri, kemudian digunakan untuk pemecahan masalah yang terjadi pada situasi nyata (Astuti 2018).

Menurut Permendiknas RI No. 19 tahun 2005 tentang Standar Nasional Pendidikan pasal 1 No. 14, pendidikan dalam mata pelajaran matematika bertujuan agar siswa memiliki kemampuan sebagai berikut:

1. Memahami konsep matematika, menjelaskan keterkaitan antar konsep dan mengaplikasikan konsep atau algoritma, secara luwes, akurat, efisien, dan tepat, dalam pemecahan masalah

2. Menggunakan penalaran pada pola dan sifat, melakukan manipulasi matematika dalam membuat generalisasi, menyusun bukti, atau menjelaskan gagasan dan pernyataan matematika

3. Memecahkan masalah yang meliputi kemampuan memahami masalah, merancang model matematika, menyelesaikan model dan menafsirkan solusi yang diperoleh

4. Mengomunikasikan gagasan dengan simbol, tabel, diagram, atau media lain untuk memperjelas keadaan atau masalah

5. Memiliki sikap menghargai kegunaan matematika dalam kehidupan, yaitu memiliki rasa ingin tahu, perhatian, dan minat dalam mempelajari matematika, serta sikap ulet dan percaya diri dalam pemecahan masalah.

Kurikulum 2013 di tingkat dasar idealnya bertujuan menumbuhkan, memfasilitasi peserta didik untuk menguasai keterampilan berpikir kritis, mengembangkan kreativitas dan pemikiran multi perspektif. Tujuan tersebut sesungguhnya mendasari implementasi pembelajaran tematik yang menggunakan dan melalui sistem penyajian dari berbagai materi, dan berbagai sumber (Huliatunisa 2020).

Berpikir menurut (Siswono 2018) merupakan suatu kegiatan mental yang dialami seseorang bila mereka dihadapkan pada suatu masalah atau situasi yang harus dipecahkan. Berpikir kritis sama pengertiannya dengan berpikir konvergen yang berarti berpikir menuju 
satu arah yang benar atau satu jawaban yang paling tepat atau satu pemecahan dari suatu masalah (Afifah, Wahyudi, and Setiawan 2019). Dengan berpikir kritis dapat membantu siswa lebih aktif dalam proses pembelajaran (Slameto 2010). Jhonson (2010) dalam (Afifah, Wahyudi, and Setiawan 2019) berpikir kritis adalah sebuah proses yang terarah jelas dengan menggunakan kegiatan mental seperti memecahkan masalah, mengambil keputusan, menganalisis asumsi, dan melakukan penelitian ilmiah. Berpikir kritis merupakan proses mental untuk menganalisis informasi. Informasi didapat melalui pengamatan, pengalaman, komunikasi, dan membaca (Suryosubroto 2002). Abrucasto (2012) dalam (Istiqomah and Indarini 2021) berpikir kritis dimaknai proses yang sudah jelas dan sudah terarah prosesnya serta dapat digunakan sebagai kegiatan pemecahan masalah, menganalisis asumsi-asumsi, dalam pengambilan keputusan, dan juga dapat digunakan sebagai penelitian karya ilmiah. Berpikir kritis adalah sebuah bentuk kemampuan dari Critikal Thingking, ditujukan untuk siswa agar mampu dalam berpendapat dengan cara sistematis dan terorganisir. Berpikir kritis dalam kegiatan pembelajaran suatu kelas juga bertujuan agar siswa mampu menjawab sebuah pertanyaan-pertanyaan dengan kritis tidak hanya sekadar menjawab namun juga memperhatikan konsep dan prinsip contohnya apa (what), bagaimana (how), mengapa (why). Berpikir kritis seharusnya dilakukan secara bersamaan dengan kemauan berpikir kreatif. (Sintawati 2015) pentingnya memiliki kemauan berpikir kreatif merupakan salah satu alasan mengapa matematika perlu diberikan di sekolah.

Elly's dkk (2015) dalam (Astuti 2018) kemampuan berpikir kreatif merupakan kemampuan seseorang dalam mengembangkan ilmu pengetahuan dan teknologi untuk menghasilkan gagasan baru yang dapat digunakan untuk memecahkan masalah yang dihadapinya. (Filsaime 2008) kemampuan berpikir kreatif merupakan proses berpikir yang memiliki ciri-ciri kelancaran (fluency), keluwesan (flexibility), keaslian atau originalitas (originality) dan merinci atau elaborasi (elaboration); kelancaran yaitu kemampuan mengeluarkan ide atau gagasan benar sebanyak mungkin secara jelas, keluwesan merupakan kemampuan untuk mengeluarkan banyak ide atau gagasan beragam dan tidak monoton dengan melihat dari berbagai sudut pandang, originalitas merupakan kemampuan untuk mengeluarkan ide atau gagasan unik dan tidak biasanya, misalnya berbeda dari yang ada di buku atau berbeda dari pendapat orang lain, elaborasi yaitu kemampuan untuk menjelaskan 
faktor-faktor yang mempengaruhi dan menambah detail dari ide atau gagasannya sehingga lebih bernilai.

Teori Puccio dan Mudock (Duch, Groh, and Allen 2001) dalam berpikir kreatif memuat aspek keterampilan kognitif dan metakognitif antara lain mengidentifikasi masalah, menyusun pertanyaan, mengidentifikasi data relevan dan tidak relevan, produktif, menghasilkan banyak ide berbeda dan produk atau ide baru dan memuat disposisi yaitu bersikap terbuka, berani mengambil posisi, bertindak cepat, bersikap atau berpandangan bahwa sesuatu adalah bagian dari keseluruhan yang kompleks, memanfaatkan cara berpikir orang lain yang kritis, dan sikap sensitif terhadap perasaan orang lain. Pentingnya kemampuan berpikir kreatif di latihkan kepada siswa pada pembelajaran matematika, bertujuan untuk pemahaman konsep-konsep yang diperlukan dalam menyelesaikan masalah matematika dan ilmu pengetahuan lain, serta memberikan kemampuan nalar yang logis, sistematis, kritis, dan cermat serta berpikir objektif dan terbuka, yang sangat diperlukan dalam kehidupan sehari-hari (Soeviatulfitri and Kashardi 2020). (Huliatunisa, Wibisana, and Hariyani 2020) berpikir kreatif merupakan pemikiran yang bersifat keaslian, reflektif dan menghasilkan suatu produk yang kompleks dalam permasalahan matematika. Berpikir tersebut melibatkan sintesis ide-ide, membangun ide-ide baru dan menentukan efektivitasnya. Selain itu, berpikir kreatif juga berkaitan dengan kemampuan untuk membuat keputusan dan menghasilkan produk baru. Coon \& Mitterer (2014) dalam (Sun 2011) berpikir kreatif atau kreativitas merupakan aktivitas memecahkan masalah yang dilakukan melalui proses eksperiensial secara tidak sadar di dalamnya tercakup pula kelancaran dalam menghasilkan sejumlah ide, keluwesan menggunakan waktu dalam menghasilkan beragam jenis solusi, dan kebaruan ide atau solusi yang dihasilkan. Pelajar yang mampu berpikir kreatif akan mempunyai ide-ide (daya cipta) untuk menyelesaikan berbagai persoalan. Setiap siswa harus berlatih berpikir kreatif untuk menjadi produktif.

Beberapa pengertian ini menunjukkan bahwa berpikir kreatif adalah suatu aktivitas kemampuan dalam mengungkapkan atau memecahkan masalah untuk menghasilkan dan menciptakan ide-ide baru dari konsep yang sudah dikuasai sebelumnya. Kemampuan merupakan suatu tindakan yang dapat dilakukan seseorang sesuai dengan tingkat pengetahuan, dan penalaran, berkaitan dengan kehidupan masyarakat, secara keseluruhan dapat diperoleh dari beragam pengalaman atau tindakan. Kemampuan sejatinya telah ada 
dalam setiap diri manusia dari sejak lahir, sehingga hanya butuh cara dan strategi bagaimana setiap kemampuan beragam tersebut dapat dikembangkan sesuai dengan taraf kemampuannya (Huliatunisa, Wibisana, and Hariyani 2020). Kemampuan merupakan daya untuk melakukan suatu tindakan sebagai hasil dari pembawaan dan latihan yang harus terus dikembangkan melalui indikator tertentu. Indikator kemampuan berpikir kreatif dalam pelajaran matematika menurut (Munandar 2020) terdapat 4 komponen yaitu, Berpikir Lancar (Fluency): Mencetuskan banyak jawaban, gagasan, dan penyelesaian masalah, Berpikir Luwes (Flexibility): Menghasilkan gagasan atau jawaban yang bervariasi, Berpikir Orisinil (Originality): Mampu memodifikasi atau membuat kombinasi baru dari bagian-bagian atau unsur-unsur dan Berpikir Terperinci (Elaboration): Menambahkan atau memperinci detaildetail dari suatu objek, gagasan atau situasi sehingga menjadi lebih baik. (Siswono 2018) mengembangkan level penjenjangan tingkat berpikir kreatif ini terdiri dari lima tingkatan yaitu; tingkat berpikir kreatif 4 (sangat kreatif), tingkat berpikir 3 (kreatif), tingkat berpikir 2 (cukup kreatif), tingkat berpikir kreatif 1 (kurang kreatif), dan tingkat berpikir kreatif 0 (tidak kreatif).

Tabel 1

Tingkat Berpikir Kreatif Matematis (TBKM)

\begin{tabular}{ll}
\hline $\begin{array}{l}\text { Tingkat Berpikir Kreatif Matematis } \\
\text { (TBKM) }\end{array}$ & Karakteristik \\
Tingkat 4 (sangat kreatif) & $\begin{array}{l}\text { Peserta didik mampu menunjukkan, fleksibilitas dan } \\
\text { kebaruan dalam memecahkan maupun mengajukan } \\
\text { masalah }\end{array}$ \\
Tingkat 3 (kreatif) & $\begin{array}{l}\text { Peserta didik mampu menunjukkan kefasihan dan } \\
\text { kebaruan atau kefasihan dan fleksibilitas dalam } \\
\text { memecahkan maupun mengajukan masalah }\end{array}$ \\
Tingkat 2 (cukup kreatif) & $\begin{array}{l}\text { Peserta didik mampu menunjukkan kebaruan atau } \\
\text { fleksibilitas dalam memecahkan maupun mengajukan } \\
\text { masalah } \\
\text { Peserta didik mampu menunjukkan kefasihan dalam } \\
\text { memecahkan maupun mengajukan masalah }\end{array}$ \\
Tingkat 1 (kurang kreatif) 0 (tidak kreatif) & $\begin{array}{l}\text { Peserta didik tidak mampu menunjukkan ketiga aspek } \\
\text { indikator berpikir kreatif }\end{array}$ \\
\hline
\end{tabular}

Komponen berpikir kreatif, menurut Munandar (1999) dalam (Susanto 2013) sedikitnya meliputi fluency, flexibility, elaboration, dan originality. Pertama, keterampilan berpikir lancar (fluency). Ciri-ciri berpikir lancar, yaitu mencetuskan banyak gagasan, jawaban, penyelesaian masalah atau pertanyaan, memberikan banyak cara atau saran untuk melakukan berbagai hal, selalu memikirkan lebih dari satu jawaban. Kedua, keterampilan berpikir luwes 
(flexibility). Ciri-ciri keterampilan berpikir luwes, yaitu: menghasilkan gagasan jawaban atau pertanyaan lebih bervariasi; dapat melihat masalah dari sudut pandang berbeda-beda; mencari banyak alternative atau arah berbeda-beda; mampu mengubah cara pendekatan atau cara pemikiran. Ketiga, keterampilan berpikir orisinil (originality). Ciri-ciri keterampilan orisinil, yaitu mampu mengungkapkan hal baru dan unik, memikirkan cara tidak lazim untuk mengungkapkan diri, mampu membuat kondisi tidak lazim dari bagian-bagian atau unsurunsur. Keempat, keterampilan memerinci (elaboration). Ciri-ciri keterampilan memerinci, yaitu: mampu memperkaya dan mengembangkan suatu gagasan atau produk; menambah atau memerinci secara detail dari suatu objek, gagasan atau situasi sehingga menjadi lebih menarik.

Beberapa teori di atas mengindikasikan bahwa matematika mempunyai karakteristik berbeda dengan mata pelajaran non matematika. Di dalam matematika mengandung karakteristik ilmu memecahkan masalah, sehingga ini berkaitan dengan kemampuan siswa untuk dapat berpikir kreatif matematis. (Huliatunisa, Wibisana, and Hariyani 2020) kemampuan berpikir kreatif matematis adalah kesanggupan seseorang dalam melakukan suatu tindakan untuk meningkatkan potensi yang dimilikinya berdasarkan kombinasi 2 perangkat faktor kemampuan, yakni kemampuan intelektual yang mengarah pada mental untuk berpikir, menalar dan memecahkan masalah, serta kemampuan fisik yang lebih mengarah kepada tugas-tugas yang menuntut stamina, keterampilan, kekuatan dan karakteristik serupa, keduanya digunakan ketika individu memunculkan suatu ide baru, di mana ide tersebut merupakan hasil dari tingkat berpikir kreatifnya yang dirancang dalam pemikirannya sendiri. Manfaat dari kemampuan berpikir kreatif matematis akan memunculkan ide-ide baru atau gagasan spontan dan terkadang tanpa direncanakan sebelumnya dalam pemikiran individu, sehingga akan mendatangkan pemikiran dan jawaban kreatif dan bervariasi pada setiap persoalan yang dihadapi. Indikasi dari berpikir kreatifnya yaitu produk aktivitas mental yang mempunyai sifat kebaruan dan bernilai baik secara subjektif dan objektif, proses berpikirnya juga baru, artinya memerlukan suatu transformasi ide-ide yang diterima maupun ditolak sebelumnya, serta proses berpikir yang di karakteristikkan oleh adanya motivasi kuat dan stabil, teramati pada periode waktu lama atau dengan tingkat intensitas tinggi. Sehingga dengan kemampuan berpikir kreatif matematis ini di harapkan individu dapat mampu memecahkan masalah dengan cara menemukan kombinasi atau mendapatkan pemikiran lebih 
terperinci dari sejumlah aturan yang dapat diterapkan dalam upaya mengatasi situasi baru yang ditemuinya, dengan menggunakan beberapa strategi, seperti mengorganisasi data dalam bentuk tabel, menduga dengan cerdas dan menguji secara kontinu, mulai menyelesaikan masalah dari yang sederhana dan relevan, melakukan simulasi kondisi pada masalah nyata, melakukan strategi melalui penalaran logis, dan secara keseluruhan dilakukan secara rutin, memilih prosedur tepat, mereduksi permasalahan nyata, dan evaluasi berkala.

Pentingnya penelitian ini dilakukan, selain teori di atas, juga dikuatkan hasil penelitian; (Husen 2016) 'Peningkatan Kemampuan Berpikir Kreatif Siswa Melalui Penerapan Model Problem Based Learning' sangat berdampak baik pada peningkatan berpikir kreatif siswa. (Cahyaningsih and Ghufron 2016) 'Pengaruh Penggunaan Model Problem Based Learning Terhadap Karakter Kreatif Dan Berpikir Kritis Dalam Pembelajaran Matematika' ada pengaruh yang signifikan dari model Problem Based Learning (PBL) terhadap peningkatan karakter kreatif dan kemampuan berpikir kritis matematika siswa setelah mengikuti pembelajaran dengan model Problem Based Learning (PBL). (Istiqomah and Indarini 2021) Penelitiannya bertujuan untuk mengetahui perbedaan komparasi keefektifan model pembelajaran Problem Based Learning dan Problem Posing untuk meningkatkan kemampuan Berpikir Kritis pada pembelajaran Matematika siswa Sekolah Dasar menggunakan metode meta analisis. Pernyataan ini mampu dibuktikan dengan mengetahui hasil uji Ancova yang menunjukkan nilai rata-rata pada skor postest terhadap model pembelajaran Problem Posing sebesar 76,2580 hasil tersebut lebih besar jumlahnya dibandingkan dengan skor rata-rata nilai postest terhadap model pembelajaran Problem Based Learning yaitu dengan jumlah 74,3620. Sejalan dengan hasil uji Ancova maka dapat ditentukan bahwa dengan menggunakan model pembelajaran tipe Problem Posing lebih efektif dibandingkan dengan model pembelajaran tipe Problem Based Learning. Berdasarkan dengan taksiran, Effect size yang dietahui dari Partial Eta Squared yang menunjukkan skor hasil dengan jumlah 0,789 dan dengan skor Sig. sebesar 0,000. Dari hasil yang sudah di temukan dan dibuktikan bahwa kedua model pembelajaran Problem Based Learning dan Problem Posing mampu memberikan pengaruh yang tergolong besar untuk meningkatkan kemampuan berpikir kritis terhadap pembelajaran matematika siswa sekolah dasar. (Sintawati 2015) pendekatan Problem Posing dan Problem Based Learning efektif ditinjau dari prestasi belajar siswa, kemampuan berpikir kreatif dan minat belajar matematika siswa. 
Selain itu diperoleh pula hasil bahwa pendekatan Problem Based Learning tidak lebih efektif dibanding pendekatan Problem Posing ditinjau dari prestasi belajar siswa, kemampuan berpikir kreatif, dan minat belajar matematika siswa.

\section{METODE PENELITIAN}

Penelitian ini dilaksanakan di SDN Cikuya III Kabupaten Tangerang, pada semester II Tahun ajaran 2018/2019. Penelitian kuantitatif ini menggunakan metode eksperimen jenis true experimental design. Populasi dalam penelitian ini seluruh siswa kelas IV SDN Cikuya III Kabupaten Tangerang berjumlah 52. Kelas IV A berjumlah 29 sebagai kelas eksperimen 1 dengan perlakuan model pembelajaran Problem Posing, dan kelas IV B berjumlah 23 sebagai kelas eksperimen 2 dengan perlakuan model pembelajaran Problem Based Learning materi bangun datar. Pengambilan sampling menggunakan teknik total sampling atau sampel jenuh. (Sugiyono 2011) sample jenuh adalah teknik penentuan sampel bila semua anggota populasi dijadikan sampel. Menggunakan teknik pengumpulan data melalui observasi, wawancara, dokumentasi dan tes, serta statistic deskriptif dan statistic inferensial sebagai teknik analisis data. Adapun indikator berpikir kreatif matematis yang digunakan sebagaimana tabel berikut: 
Tabel 2

\section{Pedoman Penskoran Instrumen Kemampuan Berpikir Kreatif Matematis}

\begin{tabular}{|c|c|c|c|}
\hline $\begin{array}{c}\text { No } \\
\text { Soal }\end{array}$ & Aspek yang diukur & Keterangan & skor \\
\hline \multirow[t]{6}{*}{1} & \multirow{5}{*}{$\begin{array}{l}\text { Keterampilan berfikir lancar (fluence) } \\
\text { Keterampilan berpikir lancar yaitu dapat } \\
\text { memberikan kemungkinan beberapa } \\
\text { jawaban atau cara dalam berbagai hal } \\
\text { untuk menyelesaikan masalah atau } \\
\text { pertanyaan. Seperti siswa lancar dalam } \\
\text { mengungkapkan gagasan, dan mempunyai } \\
\text { banyak gagasan dalam memecahkan suatu } \\
\text { permasalahan }\end{array}$} & $\begin{array}{l}\text { Memberikan lebih dari satu ide yang relevan } \\
\text { dan jawabannya benar }\end{array}$ & 4 \\
\hline & & $\begin{array}{l}\text { Memberikan lebih dari satu ide yang relevan } \\
\text { tapi jawabannya masih salah }\end{array}$ & 3 \\
\hline & & $\begin{array}{l}\text { Memberkan ide yang relevan tapi } \\
\text { jawabannya salah }\end{array}$ & 2 \\
\hline & & Memberikan ide yang tidak relevan & 1 \\
\hline & & $\begin{array}{l}\text { Tidak menjawab/ memberikan jawaban } \\
\text { salah }\end{array}$ & 0 \\
\hline & Skor maksimum & & 4 \\
\hline \multirow[t]{6}{*}{3} & \multirow{5}{*}{$\begin{array}{l}\text { Berpikir luwesan (flexibility) } \\
\text { Keterampilan berpikir luwes yaitu dapat } \\
\text { memberikan jawaban yang lebih bervariasi } \\
\text { karena dapat melihat masalah dari sudut } \\
\text { pandang yang berbeda-beda }\end{array}$} & $\begin{array}{l}\text { Memberikan jawaban lebih dari satu cara, } \\
\text { serta proses perhitungan dan hasilnya benar }\end{array}$ & 4 \\
\hline & & $\begin{array}{l}\text { Memberikan jawaban lebih dari satu cara } \\
\text { dan hasilnya ada yang salah karena } \\
\text { kekeliruan dalam proses perhitungan }\end{array}$ & 3 \\
\hline & & $\begin{array}{l}\text { Memberikan jawaban hanya satu cara dan } \\
\text { proses perhitungan serta hasilnya benar }\end{array}$ & 2 \\
\hline & & $\begin{array}{l}\text { Memberikan jawaban hanya satu cara dan } \\
\text { memberikan jawaban yang salah }\end{array}$ & 1 \\
\hline & & $\begin{array}{l}\text { Tidak menjawab/ memberikan jawaban } \\
\text { salah }\end{array}$ & 0 \\
\hline & Skor Maksimum & & 4 \\
\hline \multirow[t]{6}{*}{4} & \multirow{5}{*}{$\begin{array}{l}\text { Berpikir orisinil (originality) } \\
\text { Keterampilan berpikir orisinil yaitu } \\
\text { mengungkapkan suatu cara yang baru } \\
\text { dalam menyelesaikan masalah yang } \\
\text { terkadang hal tersebut tidak terfikirkan } \\
\text { oleh orang lain }\end{array}$} & $\begin{array}{l}\text { Memberikan jawaban dengan cara sendiri, } \\
\text { proses perhitungan dan hasilnya benar }\end{array}$ & 4 \\
\hline & & $\begin{array}{l}\text { Memberikan jawaban dengan cara sendiri, } \\
\text { tetapi terdapat kekeliruan dalam proses } \\
\text { perhitungan tetapi hasilnya salah }\end{array}$ & 3 \\
\hline & & $\begin{array}{l}\text { Memberikan jawaban dengan cara sendiri, } \\
\text { perhitunga sudah terarah tetapi tidak selesai }\end{array}$ & 2 \\
\hline & & $\begin{array}{l}\text { Memberikan jawaban dengan cara sendiri } \\
\text { tapi tidak dapat dipahami }\end{array}$ & 1 \\
\hline & & $\begin{array}{l}\text { Tidak menjawab/ memberikan jawaban } \\
\text { salah }\end{array}$ & 0 \\
\hline & Skor Maksimum & & 4 \\
\hline \multirow[t]{7}{*}{$2 \& 5$} & \multirow{5}{*}{$\begin{array}{l}\text { Berpikir memerinci (elaboration) } \\
\text { Keterampilan memerinci adalah mampu } \\
\text { mengembankan gagasan yang dimiliki dan } \\
\text { memerinci secara detail sehingga hal } \\
\text { tersebut menjadi lebih menarik. Seperti } \\
\text { siswa mampu mencoba secara detail } \\
\text { menyelesaikan suatu pertanyaan yang akan } \\
\text { diselesaikan }\end{array}$} & Memberi jawaban yang benar dan rinci & 4 \\
\hline & & $\begin{array}{l}\text { Terdapat kesalahan dalam jawaban disertai } \\
\text { dengan perincian yang detail }\end{array}$ & 3 \\
\hline & & $\begin{array}{l}\text { Terdapat kesalahan dalam jawaban disertai } \\
\text { kerincian yang kurang detail }\end{array}$ & 2 \\
\hline & & $\begin{array}{l}\text { Terdapat kesalahan dalam jawaban dan tidak } \\
\text { disertai perincian }\end{array}$ & 1 \\
\hline & & $\begin{array}{l}\text { Tidak menjawab/ memberikan jawaban } \\
\text { salah }\end{array}$ & 0 \\
\hline & Skor Maksimum & & 4 \\
\hline & Bobot tiap soal & & 20 \\
\hline
\end{tabular}

Nilai setiap soal $=\frac{\text { Skor perolehan peserta didik }}{\text { Skor maksimum tiap butir soal }} \times$ bobot soal 


\section{HASIL DAN PEMBAHASAN}

Kondisi siswa saat pembelajaran di kelas eksperimen 1 dan 2 cukup kondusif. Keaktifan siswa di kedua kelas cukup baik. Pertemuan pertama, peneliti menjelaskan kepada siswa materi yang akan dipelajari yaitu bangun datar. Setelah itu, siswa diberikan soal pretest dan diselesaikan secara individu. Banyak siswa tidak memahami maksud dari soal tersebut sehingga bertanya bagaimana cara menyelesaikannya. Kemudian, peneliti mencoba menjelaskan. Pertemuan kedua, peneliti menerapkan model pembelajaran di setiap masingmasing kelas untuk membantu menyelesaikan soal uraian tentang materi bangun datar. Pada saat diberikan model pembelajaran, masing-masing kelas menjadi mulai aktif, siswa lebih mudah dalam memaham soal cerita materi bangun datar, dan rasa ingin tahunya meningkat dibanding sebelum diberikan model pembelajaran. Pertemuan ketiga, siswa diberikan soal postest yang soalnya sama dengan soal pretest ketika belum diberikan model pembelajaran.

Data pretest diperoleh nilai rata-rata kelas eksperimen 1 lebih rendah dari kelas eksperimen 2. Hasil uji normalitas menggunakan chi kuadrat menunjukkan bahwa data pretest kelas eksperimen 1 dan kelas eksperimen 2 berasal dari sampel berdistribusi normal. Selanjutnya dilakukan uji homogenitas menggunakan uji Fisher dan diperoleh hasil bahwa data pretest kelas eksperimen 1 dan kelas eksperimen 2 berasal dari populasi homogen. Untuk mengetahui ada atau tidaknya perbedaan kemampuan berpikir kreatif siswa antara kelas eksperimen 1 dan kelas eksperimen 1, maka dilakukan uji perbedaan dengan uji-t. Sehingga diperoleh $t_{\text {hitung }}<\mathrm{t}_{\text {tabel }}$ yaitu $-1,073<2,01$, maka $\mathrm{H}_{0}$ diterima, hal tersebut menunjukkan tidak terdapat perbedaan kemampuan berpikir kreatif matematis kelas eksperimen 1 dan 2. Dengan mengetahui tidak terdapat perbedaan pada data pretest, maka peneliti menerapkan model pembelajaran Problem Posing pada kelas eksperimen 1 dan Problem Based Learning pada kelas eksperimen 2, selanjutnya setelah diberikan perlakuan maka diambil data postest dari kedua kelas.

Hasil data postest diperoleh nilai rata-rata kelas eksperimen 1 lebih rendah dari kelas eksperimen 2. Hasil uji normalitas menggunakan chi kuadrat menunjukkan bahwa data postest kelas eksperimen 1 dan 2 berasal dari sampel berdistribusi normal. Selanjutnya dilakukan uji homogenitas menggunakan Uji-Fisher dan diperoleh hasil nilai postest kelas eksperimen 1 dan 2 berasal dari populasi homogen. Untuk mengetahui ada atau tidaknya perbedaan kemampuan berpikir kreatif siswa antara kelas eksperimen 1 yang diberikan model 
Problem Posing dan kelas eksperimen 2 diberi model Problem Based Learning, maka dilakukan uji perbedaan dengan uji-t. Sehingga diperoleh nilai $t_{\text {hitung }}<t_{\text {tabel }}$, yaitu $0,09<2,01$, maka $\mathrm{H}_{0}$ diterima, hal ini menunjukkan tidak terdapat perbedaan kemampuan berpikir kreatif antara kelas eksperimen 1 yang diberi model Problem Posing dan kelas eksperimen 2 dengan model Problem Based Learning.

Walaupun hasil postest saat dihitung pada uji-t tidak terdapat perbedaan antara kelas yang diberikan model Problem Posing dan Problem Based Learning tetapi terdapat salah satu pendekatan yang memiliki pencapaian nilai rata-rata tertinggi, yaitu model Problem Based Learning dengan nilai rata-rata lebih tinggi dari nilai model Problem Posing. Di karenakan siswa pada model Problem Based Learning memiliki tahapan-tahapan sistematis dalam mengerjakan soal uraian cerita.

\section{SIMPULAN DAN SARAN}

Hasil pengujian hipotesis uji-t menunjukkan bahwa t-hitung lebih kecil dari t-tabel. Untuk pengujian hipotesis pretest dalam penelitian ini digunakan uji-t, dari hasil uji-t di peroleh thitung $=-1,073$ dan tabel $=2,01$, maka dapat disimpulkan bahwa tidak terdapat perbedaan signifikan antara nilai pretest kelas eksperimen 1 dan kelas eksperimen 2 . Sedangkan untuk pengujian hipotesis postest dari hasil uji-t diperoleh thitung $=0,09$ dan ttabel 2,01. Hasil saat uji-t tersebut menyatakan bahwa tidak terdapat perbedaan kemampuan berpikir kreatif matematis yang diberikan dengan menggunakan model Problem Posing dan model Problem Based Learning. Meskipun tidak terdapat perbedaan saat uji-t, tetapi terdapat salah satu model yang memiliki pencapaian nilai rata-rata tertinggi yaitu model Problem Based Learning dibandingkan nilai rata-rata model Problem Posing.

Kesimpulan hasil penelitian ini adalah model Problem Posing yang diterapkan di kelas IV A memiliki nilai yang lebih tinggi dari nilai sebelum diberikan model Problem Posing. Untuk model Problem Based Learning yang diterapkan pada kelas IV B memiliki nilai lebih tinggi dari nilai sebelum diberikan model Problem Based Learning dengan nilai postest. Sehingga model pembelajaran yang layak digunakan untuk meningkatkan kemampuan berpikir kreatif matematis siswa pada mata pelajaran matematika materi bangun datar siswa kelas IV SDN Cikuya III Kabupaten Tangerang adalah Problem Based Learning. 


\section{DAFTAR PUSTAKA}

Afifah, Elva Pristy, Wahyudi Wahyudi, and Yohana Setiawan. 2019. "Efektivitas Problem Based Learning Dan Problem Solving Terhadap Kemampuan Berpikir Kritis Siswa Kelas V Dalam Pembelajaran Matematika." MUST: Journal of Mathematics Education, Science and Technology 4(1): 95-107.

Ahmadi, Iif Khoiru, and Sofan Amri. 2014. Jakarta: Prestasi Pustaka Pengembangan Dan Model Pembelajaran Tematik Integratif. Jakarta: Prestasi Pustaka.

Ali Hamzah, Muhlisrarini. 2014. Jakarta: Raja Grafindo Persada Perencanaan Dan Strategi Pembelajaran Matematika. Jakarta: Raja Grafindo Persada.

Arends. R. I. 2012. "Learningtoteach(9thed)."

Astuti, Wahyu Puji. 2018. "Efektivitas Model Pembelajaran Problem Based Learning Dan Problem Solving Terhadap Kemampuan Berpikir Kreatif Matematika Siswa Kelas 4.” Jurnal Imiah Pendidikan dan Pembelajaran 2(2).

Cahyaningsih, Ujiati, and Anik Ghufron. 2016. "Pengaruh Penggunaan Model Problem-Based Learning Terhadap Karakter Kreatif Dan Berpikir Kritis Dalam Pembelajaran Matematika.” Jurnal Pendidikan Karakter (1).

Duch, Barbara J, Susan E Groh, and Deborah E Allen. 2001. The Power of Problem-Based Learning: A Practical" How to" for Teaching Undergraduate Courses in Any Discipline. Stylus Publishing, LLC.

English, Lyn D. 1995. Mathematics Education: Models and Processeso. New Jersey: Marwah: Lawrence Erlbaum Associatesm, Inc.

Filsaime, Dennis K. 2008. Jakarta: prestasi pustaka Menguak Rahasia Berpikir Kritis Dan Kreatif. Jakarta: Prestasi Pustaka.

Heruman. 2014. Model Pembelajaran Matematika. Bandung: PT Remaja Rosdakarya.

Huliatunisa, Yayah. 2020. "Upaya Meningkatkan Kemampuan Menulis Puisi Melalui Penggunaan Teknik Akrostik Pada Pembelajaran Tematik.” DIDAKTIKA TAUHIDI: Jurnal Pendidikan Guru Sekolah Dasar 7(2): 121-33.

Huliatunisa, Yayah, Elang Wibisana, and Lensi Hariyani. 2020. "Analisis Kemampuan Berfikir Kreatif Matematis Siswa Dalam Menyelesaikan Soal Pemecahan Masalah.” Indonesian Journal of Elementary Education 1(1).

Husen, Dwi Nastuti. 2016. "Peningkatan Kemampuan Berpikir Kreatif Siswa Melalui Penerapan Model Problem Based Learning." BIOEDUKASI 3(2). http://ejournal.unkhair.ac.id/Index.Php/Bioedu/Article/Download/109/83 . 
Istiqomah, Jaya Yanti Nur, and Endang Indarini. 2021. "Meta Analisis Efektivitas Model Problem Based Learning Dan Problem Posing Terhadap Kemampuan Berpikir Kritis Siswa Sekolah Dasar Pada Pembelajaran Matematika.” Jurnal Cendekia: Jurnal Pendidikan Matematika 5(1): 670-81.

Kilic, Cigdem. 2013. “Turkish Primary School Teachers' Opinions about Problem Posing Applications: Students, the Mathematics Curriculum and Mathematics Textbooks." Australian Journal of Teacher Education 38(5): 144-55.

Kreitner, Robert, and Angelo Kinicki. 2014. Jakarta: Karya Salemba Empat Perilaku Organisasi Edisi Sembilan.

Lavy, Ilana, and Atara Shriki. 2007. "Problem Posing as a Means for Developing Mathematical Knowledge of Prospective Teachers." In Proceedings of the 31st Conference of the International Group for the Psychology of Mathematics Education, ERIC, 129-36.

Mairing, Jackson Pasini. 2018. "Pemecahan Masalah Matematika, Cara Siswa Memperoleh Jalan Untuk Berpikir Kreatif Dan Sikap Positif.” Bandung: Alfabeta.

Majid, Abdul. 2014. "Pembelajaran Tematik Terpadu."

Miftahul, Huda. 2013. "Model-Model Pengajaran Dan Pembelajaran.” Yogyakarta: Pustaka Pelajar 49.

Munandar, Utami. 2020. Mengembangkan Bakat Dan Kreativitas Anak Sekolah. Jakarta: PT Gramedia.

Nasional, Departemen Pendidikan. 2006. "Permendiknas No. 22 Tahun 2006 Tentang Standar Isi." Jakarta: Depdiknas.

Ngalimun. 2013. Strategi Dan Model Pembelajaran. Aswaja Pre. Yogyakarta.

Rozak, Abdul. 2014. Repository FKIP Unswagati “Membaca Sastra Dalam Kurikulum 2013.”

Septian, Ari, and Riki Rizkiandi. 2017. "Penerapan Model Problem Based Learning (PBL) Terhadap Peningkatan Kemampuan Berpikir Kreatif Matematis Siswa." Prisma 6(1): 1-8.

Silver, Edward A. 1994. "On Mathematical Problem Posing.” For the learning of mathematics 14(1): $19-28$.

Sintawati, Mukti. 2015. "Keefektifan Problem-Based Learning Dan Problem Posing Dalam Pembelajaran Matematika." In Seminar Nasional Matematika Dan Pendidikan Matematika $U N Y$, , 225-32.

Siswono, T.Y. 2018. Pembelajaran Matematika Berbasis Pengajuan Dan Pemecahan Masalah. Bandung: PT Remaja Rosdakarya.

Slameto. 2010. Rineka cipta Belajar Dan Faktor-Faktor Yang Mempengaruhinya. Jakarta.

Soeviatulfitri, Soeviatulfitri, and Kashardi Kashardi. 2020. "Kemampuan Berpikir Kreatif Matematis 
Siswa Melalui Model Problem Based Learning (PBL) Dan Model Pembelajaran Osborn Di SMP.” Jurnal Pendidikan Matematika Raflesia 5(3): 35-43.

Sugiyono, Prof. 2011. "Metodologi Penelitian Kuantitatif Kualitatif Dan R\&D.” Alpabeta, Bandung.

Sukmadinata, Nana Syaodih. 2019. Landasan Psikologi Proses Pendidikan. Bandung: PT Remaja Rosdakarya.

Sun, Pheng Kheng. 2011. Yogyakarta: Samudra Biru Menikmati Belajar Secara Kreatif. Yogyakarta: Samudra Biru Yogyakarta.

Suryosubroto, Buang. 2002. Proses Belajar Mengajar Di Sekolah Wawasan Baru: Beberapa Metode Pendukung Dan Beberapa Komponen Layanan Khusus. Jakarta: PT Rineka Cipta.

Susanto, Ahmad. 2013. Teori Belajar Dan Pembelajaran Di Sekolah Dasar. Jakarta: Kencana prenada media group.

Tan, Weihua, and Ken Simpson. 2008. "Overseas Educational Experience of Chinese Students: An Evaluation of Service Quality Experience in New Zealand." Journal of Research in International Education 7(1): 93-112.

Wulandari, Wahyu. 2020. "Efektivitas Model Pembelajaran Problem Solving Dan Problem Posing Ditinjau Dari Kemampuan Berpikir Kritis Matematika Siswa Kelas 4.” Jurnal Sekolah Dasar 5(1): $1-10$. 